\title{
The BTPABA pancreatic function test in giardiasis
}

\author{
MITSUO OKADA* \\ M.D. \\ SEIRAI RI \\ M.D.
}

\author{
TADAHIKO FUCHIGAMI \\ M.D.
}

NORIO KOHROGI

M.D.

\section{Summary}

The test for exocrine pancreatic function using $\mathbf{N}$ benzoyl-L-tyrosyl-p-aminobenzoic acid (BTPABA test) was assessed in 7 patients with giardiasis and 7 healthy controls. Cumulative percent $p$-aminobenzoic acid (PABA) recovery in $6 \mathrm{hr}$ was significantly lower in patients with giardiasis, compared with the control group. When an equivalent dose of free PABA was given, there were no differences in PABA recovery between the groups. In patients with giardiasis, the post-treatment values of BTPABA test were significantly higher than the pretreatment values and no differences were found in PABA recovery between patients with giardiasis after eradication and healthy controls. These findings indicate that Giardia lamblia interferes with the action of pancreatic chymotrypsin. It is noteworthy that giardiasis could cause an abnormal BTPABA test.

KEY WORDS: pancreatic function, BTPABA, giardiasis.

\section{Introduction}

Although giardiasis as a cause of diarrhoea, malabsorption and biliary tract dysfunction (Petersen, 1972; Ericraizman, 1976; Goldstein, Thornton and Szydrowski, 1978; Jahadi, 1978) has been increasingly recognized in the world, little attention has been paid to the assessment of exocrine pancreatic function in patients with giardiasis. The present study reports that Giardia lamblia interferes with the action of pancreatic chymotrypsin.

\footnotetext{
*Correspondence: M. Okada, M.D.
}

\section{Patients}

Fourteen subjects were studied, 7 controls and 7 patients.

\section{Controls}

There were 5 men and 2 women healthy volunteers, aged 21-78 years (mean 49.1). In none was there clinical or laboratory evidence of gastrointestinal, hepatobiliary, pancreatic, or renal disease. There was no history of alcoholism.

\section{Patients}

Seven consecutive patients with giardiasis, 6 men and one woman, admitted to our clinic during the period from October 1979 to. December 1981, were studied. The ages ranged from 27 to 59 years (mean 39.7). The diagnosis of giardiasis was confirmed by both stool examination and microscopic examination of the duodenal aspirate. Of these, 5 patients had symptoms such as upper abdominal pain, low grade fever, general malaise, and soft stool. The remaining two patients were asymptomatic; one admitted for acromegaly, the other for a check-up. All patients had normal renal and liver function values and normal findings on oral cholecystography, barium meal and small intestinal $X$-rays. In no patient was there a history of alcoholism.

\section{Methods}

The following were performed to all subjects: (1) $N$-benzoyl-L-tyrosyl-p-aminobenzoic acid (BTPABA) test. After an overnight fast, urine was 
collected before, and for $6 \mathrm{hr}$ after, the oral administration of $0.5 \mathrm{~g}$ BTPABA containing $169.5 \mathrm{mg}$ of p-aminobenzoic acid (PABA); (2) free PABA test. Within 4 days after the BTPABA test, a similar procedure was carried out except that the peptide dose was replaced by an equimolar dose $(169.5 \mathrm{mg})$ of free PABA (Eizai Co., Tokyo, Japan).

The concentration of aromatic amines in urine was determined by the method of Bratton and Marshall (1939), as modified by Smith et al. (1945). Total recovery of PABA in the $6 \mathrm{hr}$ urine samples was expressed as a percentage of the oral dose given as follows:

$$
\% \text { recovery }=\frac{\text { total aromatic amines }(\mathrm{mg})}{169.5 \mathrm{mg} \text { of PABA }} \times 100 .
$$

In patients with giardiasis, metronidazole $250 \mathrm{mg}$ thrice daily for 10 days was used to eradicate the parasite. Eradication was confirmed by both stool examination and microscopic examination of duodenal aspirates. At least a fortnight after proven eradication, the above tests were repeated.

For comparison of results in different groups, Student's $t$-test was used. Paired $t$-test was used for paired data samples.

\section{Results}

The results of the BTPABA test are shown in Fig. 1 as the recovery rate of PABA in the urine per $6 \mathrm{hr}$. Values of the control group averaged $81 \cdot 3 \pm 8.4 \%$ (mean \pm 1 s.d.) compared with $64.4 \pm 6.8 \%$ in giardiasis. A complete separation was obtained between the two groups. The difference in the values of the two groups was highly significant $(P<0.005)$.

The results of the free PABA test are shown in Fig. 2. Values in the control group were $86.9 \pm 5.9 \%$ compared with $84.3 \pm 5.3 \%$ in giardiasis, a difference that was not statistically significant.

In patients with giardiasis, the results of the BTPABA test were compared before and after eradication (Fig. 3). The recovery rate of PABA was significantly higher after treatment $(P<0 \cdot 001)$. With therapy, the symptoms disappeared in 5 patients who had symptoms before treatment. There were no significant differences between patients with giardiasis after eradication and the controls.

\section{Discussion}

Giardia lamblia is an inhabitant of the upper gastrointestinal tract close to the opening of the pancreatic duct. Thus, it was proposed that the protozoon caused pancreatic insufficiency by invading the pancreatic duct (DeMuro, 1939). However, little information is available in the literature regard-

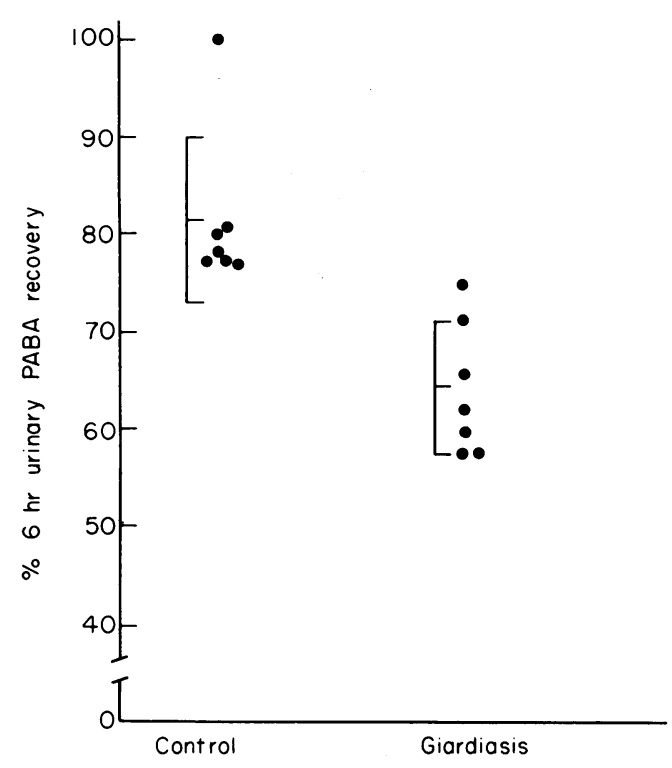

Fig. 1. BTPABA test. Cumulative $6 \mathrm{hr}$ PABA recovery (mean \pm s.d. in the control group and the giardiasis group. The values in the control group average $81.3 \pm 8.4$ and in giardiasis $64.4+6.80$ $(P<0.005)$.

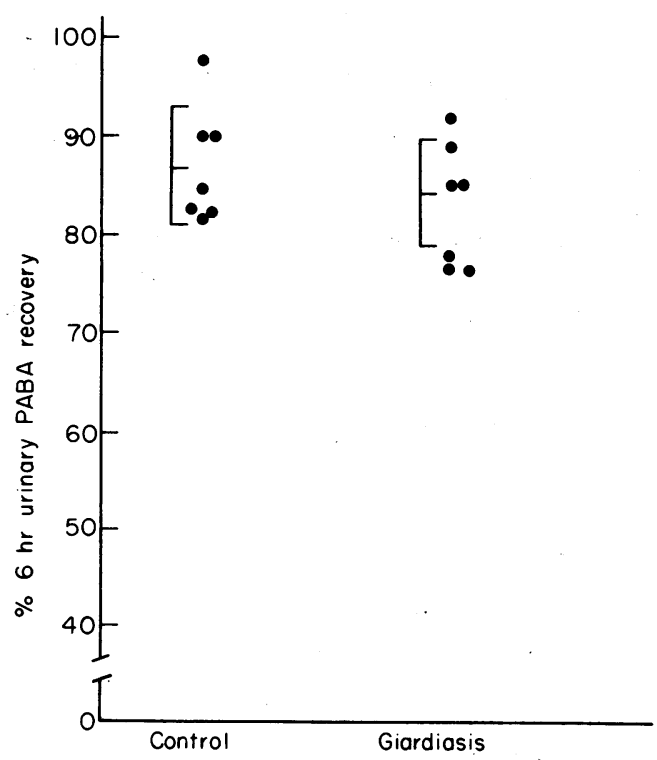

FIG. 2. Free PABA test. Cumulative $6 \mathrm{hr}$ PABA recovery ${ }^{-}$ (mean \pm s.d.) in the control group and the giardiasis group. The mean values in the control group are $86.9 \pm 5.9$ and in giardiasiso $84 \cdot 3 \pm 5 \cdot 3$. 


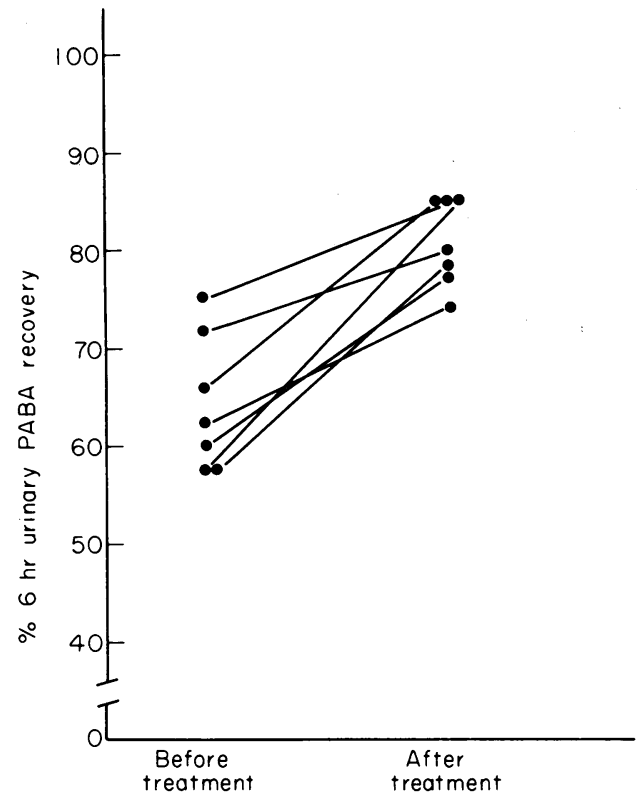

FIG. 3. BTPABA test. Cumulative $6 \mathrm{hr}$ PABA recovery before and after treatment of giardiasis. There is a significant rise in the PABA recovery after treatment $(P<0.001)$.

ing the status of pancreatic enzymes in giardiasis. Gupta and Mehta (1973) and Chawla et al. (1975) reported that tryptic activity in the duodenal aspirate was significantly lower in patients with giardiasis in comparison with the controls and a significant improvement occurred after eradication.

BTPABA, a synthetic peptide used for an exocrine pancreatic function test (BTPABA test), is specifically cleaved by pancreatic chymotrypsin and the released PABA is rapidly absorbed from the small intestine, conjugated in the liver and excreted in the urine (Imondi, Stradley and Wolgemuth, 1972; deBenneville et al., 1972). Accordingly, the amount of PABA recovered in the urine after oral administration of BTPABA may be used as an index of exocrine pancreatic function. Previous studies showed that the BTPABA test enabled detection of pancreatic disease and that the results correlated well with tests using duodenal intubation (Arvanitakis and Greenberger, 1976; Gyr et al., 1976; Bornschein, Goldmann and Otte, 1976; Imamura et al., 1978; Kimura, Wakasugi and Ibayashi, 1981). However, this test could produce misleadingly abnormal results in patients with malabsorption, liver disease or renal disease, because recovery of PABA in the urine depends not only on chymotrypsin hydrolysis but also on the absorption, conjugation and excretion of PABA. Such misleading results can be excluded by performing a test (free
PABA test), replacing oral BTPABA with PABA, to correct for abnormal PABA absorption, metabolism and excretion (Mitchell et al., 1979, 1981; Kimura et al., 1979).

In our study, the recovery rate of PABA in the BTPABA test was significantly lower in patients with giardiasis than in the controls, though in the free PABA test no differences were found between the groups. Moreover, in patients with giardiasis, the post-treatment values in the PTPABA test were significantly higher than the pretreatment values. These findings indicate that Giardia lamblic interferes with the action of pancreatic chymotrypsin.

Although its exact cause is unclear, there seem to be several possible mechanisms-direct pancreatic parenchymal damage, mechanical blockage of pancreatic duct, interference with the activating system of pancreatic enzymes in the duodenum and production of inhibitor of pancreatic enzymes, and bacterial overgrowth interfering with chymotrypsin activation.

\section{References}

ARvanitakis, C. \& Greenberger, N.J. (1976) Diagnosis of pancreatic disease by a synthetic peptide. A new test of exocrine pancreatic function. Lancet, i, 663 .

Bornschein, W., GoldmanN, F.L. \& OTTE, M. (1976) Methodische und erste klinische Untersuchungsergebnisse mit einem neuen indirekten Pankreasfunktionstest. Clinica chimica Acta, 67, 21.

Bratton, A.C. \& Marshall, E.K. (1939) A new coupling component for sulfamilamide determination. Journal of Biological Chemistry, 128, 537.

Chawla, L.S., Sehgal, A.K., Broor, S.L., Verma, R.S. \& ChHutTANI, P.N. (1975) Tryptic activity in the duodenal aspirate following a standard test meal in giardiasis. Scandinavian Journal of Gastroenterology, 10, 445.

DeBenneville, P.L., Godfrey, W.L., Sims, H.J. \& ImONDI, A.R. (1972) New substrates for a pancreatic exocrine function test. Journal of Medicinal Chemistry, 15, 1098.

DeMuro, P. (1939) Clinical aspects of giardiasis. Acta medica Scandinavica, 99, 78.

Ericraizman, R. (1976) Giardiasis: An overview for the clinician. American Journal of Digestive Diseases, 21, 1070.

Goldstein, F., ThORNTON, J.J. \& SzYdlowsKI, T. (1978) Biliary tract dysfunction in giardiasis. American Journal of Digestive Diseases, 23, 559.

GUPTA, P.K. \& MEhTA, S. (1973) Giardiasis in children: A study of pancreatic functions. Indian Journal of Medical Research, 61, 743.

Gyr, K., Stalder, G.A., Schiffmann, I., Fehr, C., Vonder. SCHMITT, D. \& FAHRLAENDER, H. (1976) Oral administration of a chymotrypsin-labile peptide-a new test of exocrine pancreatic function in man (PFT). Gut, 17, 27.

imamura, K., Nakamura, T., Miyazato, T., Abe, Y., Kobayashi, M., TAKEBE, K. \& TOYOTA, T. (1978) Oral administration of chymotrypsin labile peptide for a new test of exocrine pancreatic function (PFT) in comparison with pancreozymin-secretin test. American Journal of Gastroenterology, 69, 572.

IMONDI, A.R., STRADLEY, R.P. \& WolgeMUTH, R. (1972) Synthetic peptides in the diagnosis of exocrine pancreatic insufficiency in animals. Gut, 13, 726.

JAHADI, M.R. (1978) Giardiasis and intestinal malabsorption Report of a case. Disease of Colon and Rectum, 21, 372.

Kimura, T., WaKasugl, H. \& IbayaShI, H. (1981) Clinical study of exocrine pancreatic function test by oral administration of $N$ benzoyl-L-tyrosyl-p-aminobenzoic acid. Digestion, 21, 133. 
Kimura, T., Wakasugi, H., Funakoshi, A., Matsumoto, M. \& IBAYASHI, H. (1979) Clinical studies on the exocrine pancreatic function test by oral administration of $N$-benzoyl-L-tyrosyl-PABA combined with the PABA absorption test. Japanese Journal of Gastroenterology, 76, 259 (in Japanese with English abstract).

MrTCHELl, C.J., HuMPHREY, C.S., BULlEN, A.W., Kelleher, J. \& LOSOWSKY, M.S. (1979) Improved diagnosis accuracy of a modified oral pancreatic function test. Scandinavian Journal of Gastroenterology, 14, 737.

Mitchell, C.J., Field, J.P., Simpson, F.G., PARKIN, A., Kelleher,
J. \& LosowsKY, M.S. (1981) Preliminary evaluation of single-dax tubeless test of pancreatic function. British Medical Journal, 282? 1753.

PETERSEN, H. (1972) Giardiasis (Lambliasis). Scandinavian Journat of Gastroenterology, 7, Suppl. 14, 1.

Smith, H.W., Finkelstein, N., Aliminosa, L., Crawford, B. \&O GRABER, M. (1945) The renal clearance of substituted hippuriof acid derivatives and other aromatic acids in dog and man. Journat? of Clinical Investigation, 24, 388.

(Accepted 13 August 1982) 